\title{
Malignant melanotic schwannoma of the bronchus
}

\author{
D ROWLANDS, C EDWARDS, * F COLLINS
}

From the Departments of Histopathology and *Thoracic Surgery, East Birmingham Hospital, Birmingham

SUMMARY A case of malignant melanotic schwannoma arising in the right upper lobe bronchus of a 27 year old man is presented. Tumours of this type most commonly occur in spinal nerve roots and are generally considered to be benign. The behaviour of those originating elsewhere is less predictable. As far as we are aware this is the first reported case affecting the respiratory tract.

Melanotic schwannoma belongs to a group of neoplasms derived from the neural crest which occupy an intermediate position between melanoma and schwannoma. Over 20 cases at various sites have been documented so far. ${ }^{1-6}$ The behaviour of these tumours is extremely difficult to predict on histological grounds. The "paraxial" variant is the most common and arises in the roots of spinal nerves. Most are benign, although their site can make surgical treatment difficult. Those originating from the autonomic nervous system, soft tissues, viscera, or the acoustic nerve may behave more aggressively.

In contrast to neuroendocrine tumours of endodermal derivation ${ }^{7}$ typified by small cell carcinomas and carcinoids, tumours of neural crest origin are rare in the respiratory tract. A few cases of melanoma, ${ }^{89}$ nerve sheath tumour, ${ }^{1011}$ and meningioma ${ }^{12-14}$ have been reported, together with neoplasms associated with von Recklinghausen's disease, ${ }^{14}$ but as far as we are aware there are no reported examples of melanotic schwannoma. We report a case of malignant melanotic schwannoma originating in the right upper lobe bronchus.

\section{Case report}

A 27 year old caucasian man, who was a non-smoker, presented with a five month history of productive cough with green sputum and occasional small haemoptyses. When he was 9 years old he had been investigated for haematuria, and an apparently nonfunctioning left kidney had been found. A tendon release operation for congenital talipes equinovarus had been carried out at the age of 14 years, and he was known to have asymptomatic spina bifida occulta. At 22 years of age he had had a single grand mal seizure: a computed tomography scan of the brain was normal but there was an epileptiform focus on electro-

Accepted for publication 9 June 1987 encephalography in the left temporal region. Idiopathic epilepsy was diagnosed, and he began taking $200 \mathrm{mg}$ of carbamazepine three times a day. No further fits had occurred and no skin lesions of any type had been removed.

Examination showed that there was diffuse freckling of the face and lips, but no naevi were noted. Air entry over the right lung base was reduced, and a chest radiograph showed collapse of the basal segment of the right lower lobe. On bronchoscopy a black, polypoid tumour was seen occluding the orifice of the right upper lobe bronchus. Histological examination of the biopsy material showed a spindle cell melanotic tumour. Further investigations, including a detailed ophthalmological investigation and abdominal ultrasound scan, failed to show any abnormality other than a congenitally absent left kidney.

A right upper lobectomy with sleeve resection and full paratracheal and subcarinal lymph node clearance was carried out. The postoperative period was marred by right frontal headaches, numbness of the right side of the face, and antisocial behaviour. No neurological signs were elicited at this time, and a further computed tomography scan yielded normal results. A right trophic corneal ulcer developed, which was treated by tarsorrhaphy.

Following discharge the headaches and numbness persisted, and the patient began to notice occasional diplopia on looking downwards and to the right. Ten weeks postoperatively examination showed that there was a slight right facial hemiparesis and loss of sensation over the distribution of the right trigeminal nerve. The fundi were normal. A computed tomography scan showed a tumour on the right side of the cavernous sinus, projecting backwards into the cerebello-pontine angle, but not invading bone.

At craniotomy a soft, black, locally invasive tumour was found in the right middle fossa. It was considered to be inoperable, and a biopsy specimen 


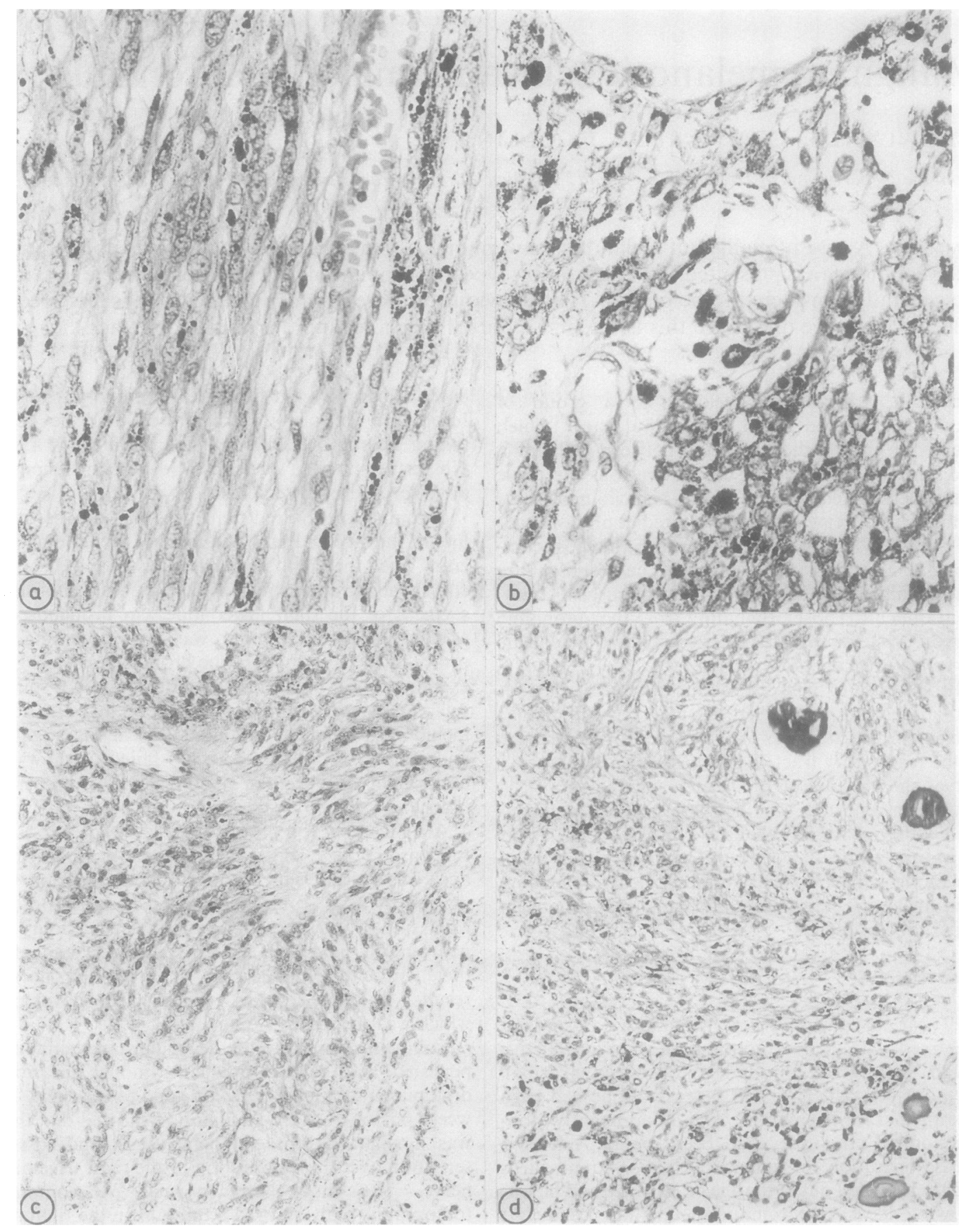

Fig 1 (a) Heavily pigmented cells in an Antoni A pattern; (b) heavily pigmented cells in an Antoni B pattern-the edge of a cystic space is present at the top of the picture; (c) organoid arrangement of cells resembling a Verocay body; (d) pigmented polygonal cells loosely arranged in sheets. Psammoma bodies are present on the right. (Haematoxylin and eosin.) 
was taken prior to closure. Histologically, it was identical with the bronchial tumour. A two week course of modified radical cranial megavoltage treatment was started, resulting in some symptomatic improvement. When last seen, 14 months from presentation, there had been slowly progressive neurological deterioration, with ataxia and persistent headaches. At the time of writing the patient was receiving terminal care.

\section{Pathology}

The operative specimen consisted of a deaerated right upper lobe 12 by 8 by $2.5 \mathrm{~cm}$, with a bronchial stump $3 \mathrm{~cm}$ long. A smooth, dark brown, polypoid and roughly spherical tumour $1 \mathrm{~cm}$ in diameter arose from the posterior aspect of the upper lobe bronchus by a broad base $0.6 \mathrm{~cm}$ across. The lumen was almost completely occluded and neoplastic tissue extended through the bronchial wall to form an extrabronchial mass $1.5 \mathrm{~cm}$ in diameter. The distal lung parenchyma appeared normal on gross examination. Three pre- tracheal and two subcarinal lymph nodes were submitted separately, the largest measuring 1.5 by 1.5 by $0.5 \mathrm{~cm}$.

The greater part of the tumour consisted of sheets and interlacing bundles of elongated cells with poorly defined borders, corresponding to an Antoni type A pattern (fig la). The cytoplasm was eosinophilic and contained abundant pigment giving a positive reaction for melanin by the Masson-Fontana method. Nuclei were round or oval, up to $15 \mu \mathrm{m}$ across, with an open chromatin pattern and often a single, rather indistinct nucleolus. There was no mitotic activity. Elsewhere there was an Antoni type B structure with large irregular cysts, some as large as $3 \mathrm{~mm}$ in diameter, lined by polygonal or flattened cells (fig lb). Occasionally there was palisading, with an attempt at Verocay body formation (fig 1c), and in some areas polygonal cells were loosely arranged in sheets (fig 1d). Immunoperoxidase staining for $\mathrm{S} 100$ protein was strongly positive and the cytoplasm was argyrophilic by the Grimelius method: the reaction for neuron specific enolase was negative. Psammoma bodies were

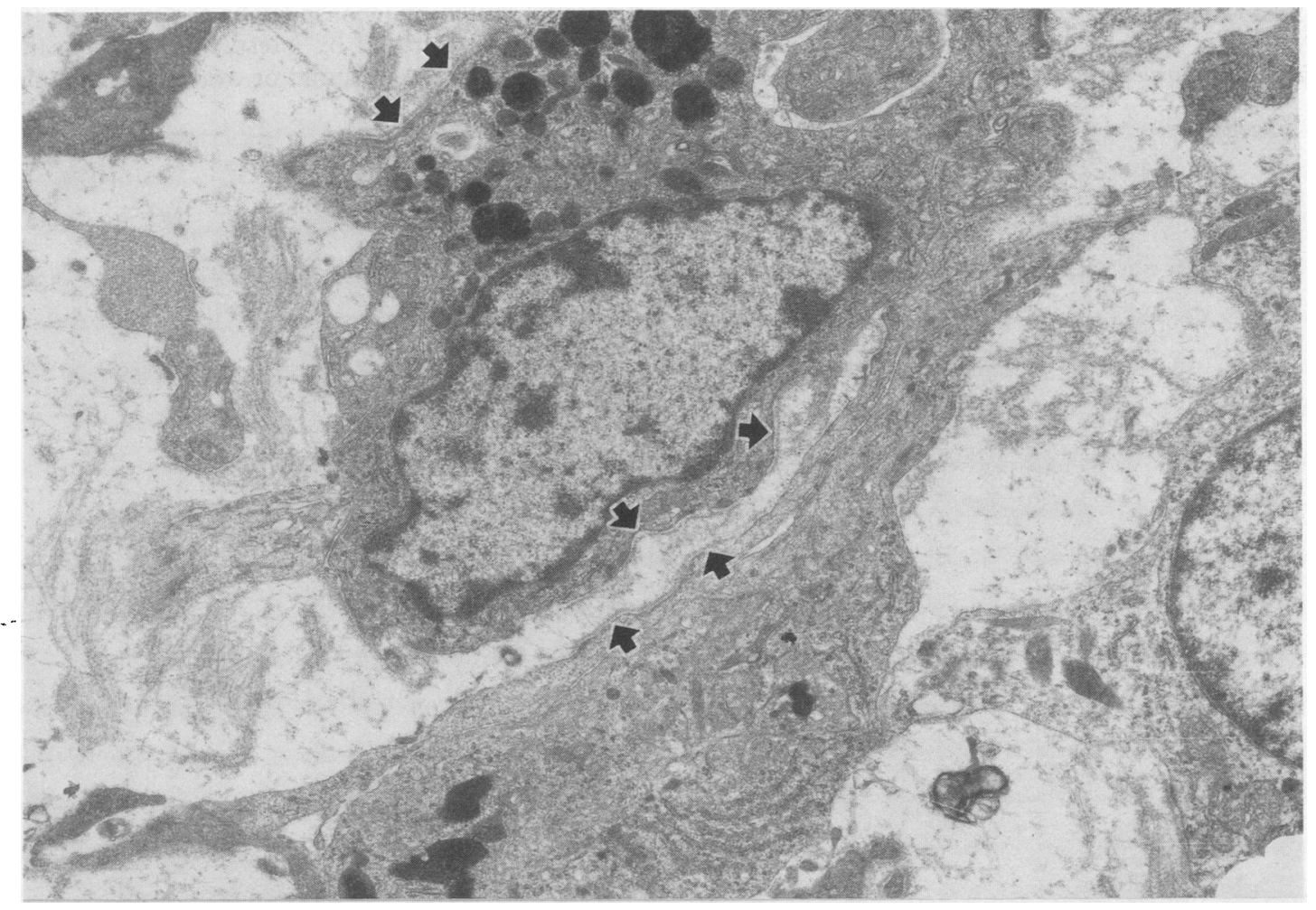

Fig 2 Polygonal cell containing mature melanosomes occupies the centre of the field, surrounded by a flocculent matrix and cytoplasmic processes from adjacent cells. Note discontinuous basal lamina (arrows) and the myelin figure at bottom right. 


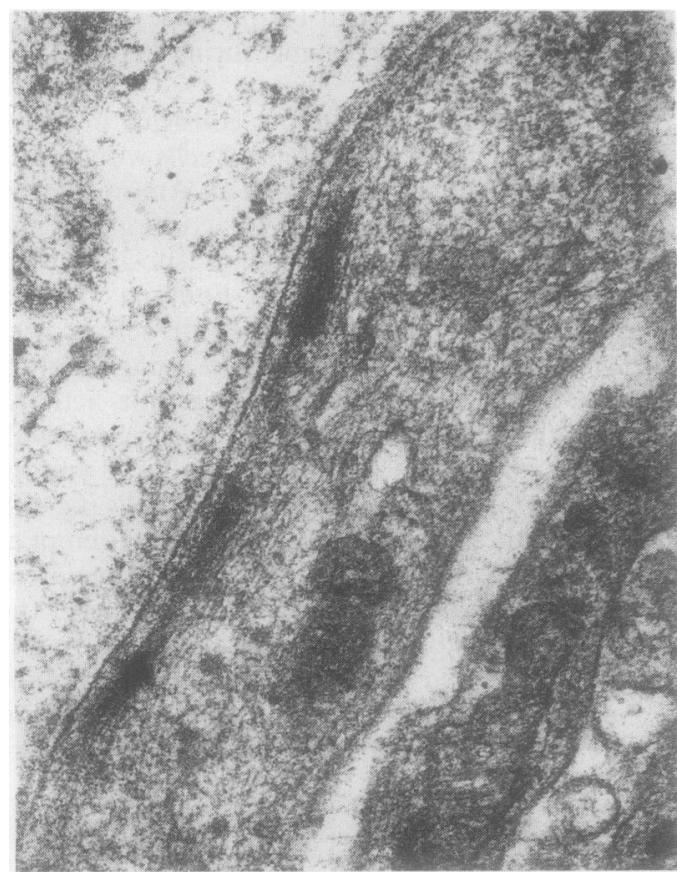

Fig 3 Cell process with basal lamina on one side. Filamentous structures are present in the cytoplasm. plentiful (fig 1d). The stroma consisted of sparse collagen fibres containing thin walled capillaries and occasional thick walled arterial vessels.

The tumour was only partly surrounded by an ill defined capsule of fibrous tissue, and there was focal infiltration of adjacent connective tissue, mucus gland, and nerve. Neoplastic tissue either extended to the basement membrane of the overlying respiratory epithelium or was separated from it by a band of vascular connective tissue up to $300 \mu \mathrm{m}$ across. There was no evidence of "junctional" activity or ulceration. The overlying epithelium was of normal respiratory type, with foci of squamous metaplasia.

Seven blocks of tissue were obtained for ultrastructural studies immediately after lobectomy, and each was conventionally processed for transmission electron microscopy. Tumour cells in this material were variable in appearance. Some were elongated or polygonal with long cytoplasmic processes, lying in a flocculant matrix containing scattered bundles of short spacing collagen (fig 2). No Luse bodies (long spacing collagen fibres) were seen. A discontinuous basal lamina was prominent in some areas (figs 2 and 3). Other cells were more closely apposed to each other and united by inconspicuous gap junctions (fig 4), or were surrounded by intertwining cytoplasmic processes. Nuclei were round or oval and sometimes

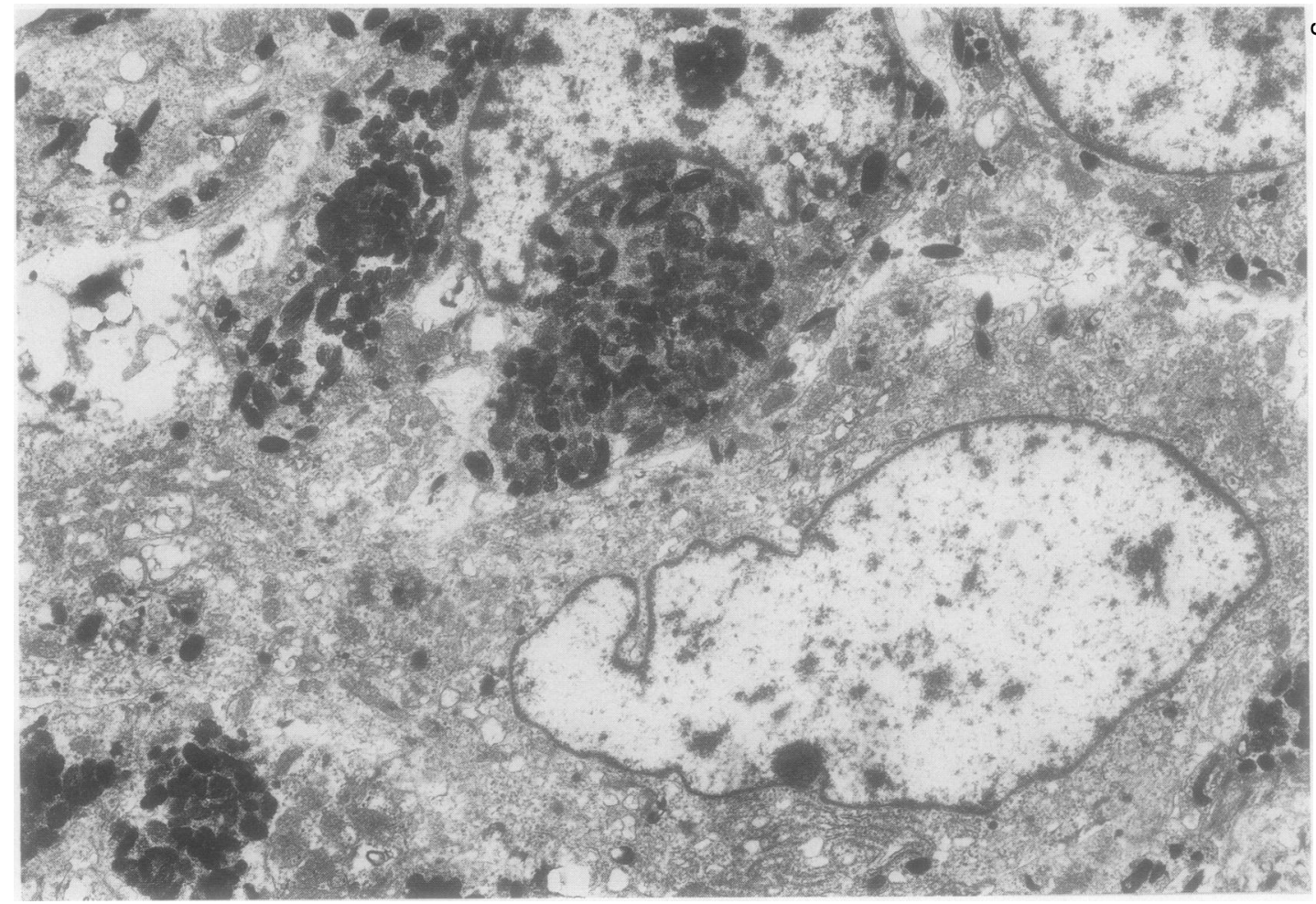

Fig 4 Closely applied polygonal cells with aggregates of melanosomes in the cytoplasm. 


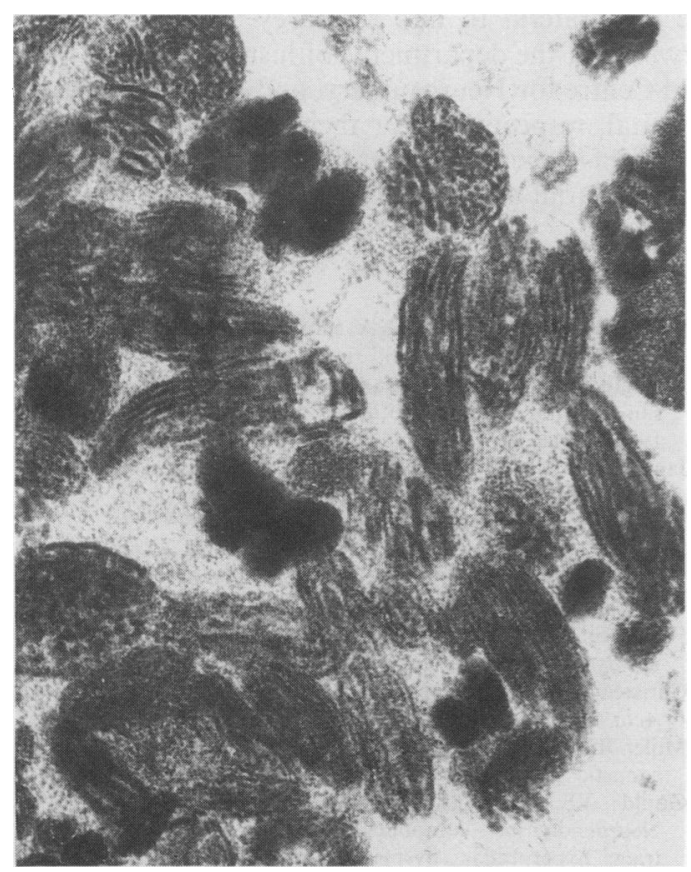

Fig 5 Aggregate of melanosomes showing different stages in maturation.

clefted, with peripheral clumping of chromatin and often a prominent nucleolus. The cytoplasm contained varying numbers of melanosomes at different levels of maturation (fig 5), ranging from those with the characteristic striated structure but little evidence of melanin deposition (stage II melanosomes) to others in which the striations were completely obliterated by pigment (stage IV melanosomes). Occasional cells contained compound melanosomes. Rough endoplasmic reticulum and free ribosomes were abundant, and a well developed Golgi zone was generally present. Mitochondria were rather scanty and often pleomorphic. Some cells contained pinocytic vesicles, and there were intermediate type filaments in cytoplasmic processes (fig 3). In some fields myelin figures were present in the cytoplasm or lying free in the adjacent matrix (fig 2). No membrane bound neurosecretory granules or microtubules were identified.

The light microscopic appearances of the bronchoscopy specimen were identical with those seen in the resected tumour. The material obtained at craniotomy was also similar, but melanin pigment was more abundant, and the cells were somewhat larger and less spindle shaped. Mitoses were scanty.

\section{Discussion}

The morphology of this tumour is characteristic of melanotic schwannoma. ${ }^{1-6}$ On light microscopy the arrangement of argyrophilic cells in an Antoni A and B pattern, the foci of palisading and Verocay body formation, and the microcystic spaces all pointed to Schwannian differentiation. S100 protein is a marker for normal and neoplastic Schwann cells and melanocytes, although not entirely specific: it is also present in skin, interdigitating reticulum cells, chondrocytes and adipocytes, but may be absent from malignant nerve sheath tumours. ${ }^{15}$ At an ultrastructural level the criteria for a tumour of Schwann cells were also fulfilled, ${ }^{16}$ the discontinuous basal lamina, and the absence of Luse bodies (long spacing collagen fibres) suggesting malignancy. ${ }^{16}$

In the past the presence of melanin in melanotic schwannoma has been explained by phagocytosis or "cytocrine injection" from nearby non-neoplastic melanocytes, neoplastic proliferation of Schwann cells, and melanocytes in the same tumour, or transformation of melanoblasts to Schwann cells. ${ }^{1-46}$ More recently it has been shown that in these tumours neoplastic Schwann cells contain stage II and III premelanosomes as well as mature stage IV melanosomes, ${ }^{1-46}$ indicating that they are capable of melanin synthesis: if the melanin had been merely phagocytosed it would appear only as membrane bound aggregates of stage IV melanosomes (compound melanosomes). Melanogenesis has also been shown in experimental tumours of nerve sheath, as well as normal dermal Schwann cells. ${ }^{146}$ This currently accepted view was in fact first proposed by Masson ${ }^{17}$ many years ago, and reflects the common origin of melanocytes and Schwann cells from the neural crest. ${ }^{1-46}$

The differential diagnosis of melanotic schwannoma includes benign and malignant melanocytic neoplasma, pigmented neurofibroma, meningioma, melanotic medulloblastoma, neuroectodermal tumour of infancy, pigmented neuroblastoma and ganglioneuroblastoma, clear cell sarcoma, ectomesenchymoma (triton tumour) and neurotropic melanoma, ${ }^{14}$ together with melanotic neuroendocrine carcinomas and carcinoids. ${ }^{1819}$ Many of these entities can be ruled out on clinical or morphological grounds.

Neuroendocrine tumours containing melanin, for instance, show the characteristic arrangement of small uniform cells with numerous neurosecretory granules, ${ }^{1819}$ and pigmented neurofibromas have the same structure as the benign cutaneous lesions of von Recklinghausen's disease. ${ }^{20}$ Malignant melanomas may consist partially or wholly of spindle shaped cells and occasionally show Schwannian features, ${ }^{21}$ but most of those reported in the lung have been of the classical type, often with junctional change in the overlying epithelium. ${ }^{89} \mathrm{~A}$ pigmented bronchial tumour described by Robertson et al, ${ }^{22}$ however, 
resembled a malignant blue naevus. Mitoses were scanty and there was no junctional activity. Unfortunately, no ultrastructural examination was carried out, and the light photomicrograph is of poor quality, but this tumour may in fact have been a malignant melanotic schwannoma.

Although psammoma bodies are not a feature of nerve sheath tumours in general, they have been reported in melanotic schwannoma. ${ }^{23}$ Their clinical importance is uncertain. They could indicate meningiomatous differentiation, as meningiomas may occur in the lung, either spontaneously or in association with von Recklinghausen's disease, ${ }^{12}{ }^{14}$ and so called minute pulmonary chemodectomas are ultrastructurally identical with such tumours. ${ }^{14}$ In the case reported here, however, there was no morphological evidence of meningiomatous differentiation, and clinically there were no stigmata of neurofibromatosis. Psammoma bodies are by no means specific to meningioma, and it has been suggested that they form around aggregates of intracytoplasmic filaments ${ }^{24}$-structures which were moderately abundant in this tumour.

Most reported cases of melanotic schwannoma have arisen in the roots of spinal nerve. ${ }^{1-4}$ For the most part such "paraxial" tumours do not metastasise. Total surgical removal may not be possible, ${ }^{25-7}$ but even if incompletely excised they respond well to radiotherapy. ${ }^{26-7}$ Some, however, behave more aggressively. Two of the four tumours described by Graham et $a^{28}$ spread into the spinal cord, and a melanotic schwannoma of the acoustic nerve recurred locally resulting in the death of the patient. ${ }^{29} \mathrm{~A}$ further patient with an acoustic nerve tumour, on the other hand, was reported to be in good health nine months postoperatively. ${ }^{6}$

The behaviour of peripheral melanotic schwannoma is less predictable. Six unequivocally malignant examples arising from the thoracic sympathetic chain have been reported, ${ }^{30-3}$ together with a single case affecting the oral cavity. ${ }^{2}$ In a case affecting the stomach, ${ }^{1}$ however, although there was invasion of smooth muscle, fat and perineurium in the gastrectomy specimen, no metastases were found at necropsy following a road accident 22 months later. Similarly, a tumour of the buttock was histologically malignant, but there was no recurrence four year postoperatively, ${ }^{5}$ and two further patients with tumours of the right atrium $^{34}$ and the thoracic sympathetic chain $^{35}$ were alive and well 14 and 20 months after surgery and radiotherapy. Five other tumours of soft tissue and a further example from the oral cavity were successfully treated by local excision. ${ }^{3}$ In two cases affecting the oesophagus ${ }^{36-7}$ and one from the retroperitoneum $^{38}$ the eventual outcome was not documented.
We are grateful to Drs M Carey, S Ghosh, and J Newman of the departments of histopathology, Midland Centre for Neurosurgery, and East Birmingham Hospital, respectively, for their help in the preparation of this paper. We are grateful to Mrs Ruth Fry for her secretarial assistance.

\section{References}

1 Burns DK, Silva FG, Forde KA, Mount PM, Clark HB. Primary melanotic schwannoma of the stomach. Evidence of dual melanocytic and schwannian differentiation in an extra-axial site in the patient without neurofibromatosis. Cancer 1983;52:1432-41

2 Janzer RC, Makek M. Intraoral malignant melanotic schwannoma. Ultrastructural evidence for melanogenesis by Schwann's cells. Arch Pathol Lab Med 1983;107:298-301.

3 Font RL, Truong LD. Melanotic schwannoma of soft tissues. Electron-microscopic observations and review of literature. Am J Surg Pathol 1984;8:129-38.

4 Erlandson RA. Melanotic schwannoma of spinal nerve origin. Ultrastruct Pathol 1985;9:123-9.

5 Christensen C. Malignant melanotic schwannoma. A case report. Acta Chir Scand 1986;152;385-6.

6 Miller RT, Sarikaya H, Sos A. Melanotic schwannoma of the acoustic nerve. Arch Pathol Lab Med 1986;220:153-4.

7 Gould VE, Linnoila RI, Memoli VA, Warren WH. Neuroendocrine components of the bronchopulmonary tract: hyperplasias, dysplasias and neoplasms. Lab Invest 1983;49:519-37.

8 Angel R, Prados M. Primary bronchial melanoma. J Louisiang State Med Assoc 1984;136:13-5.

9 Carstens PHB, Kuhns JG, Ghazi C. Primary malignant melano mas of the lung and adrenal. Hum Pathol 1984;15:910-4.

10 Muhrer KH, Fischer HP. Primary pulmonary neurilemoma Thorac Cardiovasc Surg 1983;31:313-6.

11 Roviaro G, Montorsi M, Varoli F, Binda R, Cecchetto A. Primary pulmonary tumours of neurogenic origin. Thorax 1983;38:942-5.

12 Chumas JC, Larelle CA. Pulmonary meningioma. A light and electron microscopic study. Am J Pathol 1982;6:795-801.

13 Kennitz P, Sportman H, Heinrich P. Meningioma of lung. First report with light and electron miscroscopic findings. Ultrastruct Pathol 1982;3:359-65.

14 Unger PD, Geller SA, Anderson PJ. Pulmonary lesions in a patient with neurofibromatosis. Arch Pathol Lab Med 1984;108:654-7.

15 Daimaru Y, Hashimoto H, Enjoji M. Malignant peripheral nerve-sheath tumours (malignant schwannomas). An 3 immunohistochemical study of 29 cases. Am J Surg Pathol 1985;9:434-44.

16 Chitale AR, Dickersin GR. Electron microscopy in the diagnosis of malignant schwannomas. A report of six cases. Cancer 1983;51:1448-61.

17 Masson P. Melanogenic system. Nevi and melanomas. Pathol Annu 1967;2:351-97.

18 Gould VE, Memoli VA, Dardi LE, Sornez HJ, Somers SC, N Johannessen JV. Neuroendocrine carcinomas with multiple immunoreactive peptides with melanin production. Ultrastruct $\mathrm{N}$ Pathol 1981;2:199-217.

19 Grazer R, Cohen SM, Jacobs JB, Lucas P. Melanin-containing $\omega$ peripherat carcinoid of the lung. Am J Surg Pathol 1982;6:73-8.

20 Bird CC, Willis RA. The histogenesis of pigmented 0 neurofibromas. J Pathol 1969;97:631-7.

21 Dimaio SM, Mackay B, Smith JL, Dickersin GR. Neu- $\mathscr{D}$ rosarcomatous transformation in malignant melanoma: an ultrastructural study. Cancer 1982;50:2345-54.

22 Robertson AJ, Sinclair DJM, Sutton PP, Guthrie W. Primary

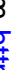
. 
melanoma of the lower respiratory tract. Thorax 1980;35:158-9.

23 Enzinger FM, Weiss SW. Soft tissue tumors. St Louis: CV Mosby, 1983.

24 Ghadially FN. Diagnostic electron microscopy of tumours. London: Butterworths, 1980.

25 Mandybur TI. Melanotic nerve sheath tumours. $J$ Neurosurg 1974;41:187-92.

26 Mennemeyer RP, Hallman KO, Hammar SP, Reisis JE, Tytus JS, Bockus D. Melanotic schwannoma. Clinical and ultrastructural studies of three cases with evidence of intracellular melanin synthesis. Am J Surg Pathol 1979;3:3-10.

27 Lowman RM, Livolsi VA. Pigmented (melanotic) schwannoma of the spinal canal. Cancer 1980;46:391-7.

28 Graham DI, Paterson A, McQueen A, Milne JA, Urich H. Melanotic tumours (blue naevi) of spinal nerve roots. J Pathol 1976;118:83-9.

29 Dastur DK, Sing G, Pandya SK. Melanotic tumour of the acoustic nerve. J Neurosurg 1967;27;166-70.

30 Millar WG. A malignant melanotic tumour of ganglion cells arising from a thoracic sympathetic ganglion. J Pathol Bacteriol 1983;35:351-7.

31 Higashino KI, Sato J. Uber ein Primares melanoganglion in hinteren mediastinum: ein Beitrag zur erkenntris der gangli- enleisten tumoren. Sci Rep Res Inst Tohoku Univ (Med) 1959;9:90-100.

32 D'Abrera V St E, Burfitt-Williams W. A melanotic neuroectodermal neoplasm of the posterior mediastinum. J Pathol 1973;111:165-71.

33 Fu Y-S, Kaye GI, Lattes R. Primary malignant melanocytic tumours of the sympathetic ganglia, with an ultrastructural study of one. Cancer 1975;36:2029-41.

34 Gelfland ET, Taylor RF, Rao S, Hendin D, Akabutu J, Callaghan JC. Melanotic malignant schwannoma of the right atrium. $J$ Thorac Cardiovasc Surg 1977;74:808.

35 Krausz T, Azzopardi JG, Pearse E. Malignant melanoma of the sympathetic chain: with a consideration of pigmented nerve sheath tumours. Histopathology 1984;8:881-94.

36 Assor D. A melanocytic tumour of the esophagus. Cancer 1975;35:1438-43.

37 Sengupta P. Melanotic oesophageal neurofibroma. J Indian Med Assoc 1982;79:101-2.

38 Theofossiou A, Segditsas T. Uber ein intraabdominal gelegenes melanotisches. Schwannom Z Allg Pathol 1971;114:168-72.

Requests for reprints to. Dr CW Edwards, Department of Histopathology, East Birmingham Hospital, Bordesley Green East, Birmingham B9 5ST, England. 